\title{
Crude Oil Price Shocks, Exchange Rate Regimes and Monetary Policy in African Oil Producing Countries
}

\author{
Adetona Sikiru Adedeji and Mojeed Olanrewaju Saliu
}

\begin{abstract}
This study investigated whether exchange rate regimes and interest rate policy have a significant explanatory power of oil price implications on African oil producing economies. Data for the study were sourced from World Development Indicators published by the World Bank and International Monetary Fund (World Economic Outlook). The study used a four variable Structural Vector Autoregressive (SVAR) model. Findings from the SVAR impulse response functions revealed that no exchange rate regime is the best, and no one is bad for African oil producing countries, judging from the costs and benefits that are associated with the three major exchange rate regimes. Findings from the study equally confirmed that expansionary monetary policy is more effective in insulating against and compensating for the negative effects of the shocks associated with the global oil price in the selected oil producing countries in Africa.
\end{abstract}

Index Terms - World Oil Price, Exchange Rate Regime, Real Interest Rate, Structural Vector Autoregressive, African Oil producing Countries.

\section{INTRODUCTION}

Crude oil is an important strategic energy for all countries in the world. It is an essential commodity that stimulate the development of modern industry and economy as it serves as an input into the production of goods and services in an economy. Moreover, movement in the price of crude oil has been regarded as the basis for a country's revenue structure and its balance of payment. Crude oil price is adjudged as the barometer of worldwide economy, whose change has a direct impact on the health of an importing or exporting economy [1]. Oil price shocks play a vital role in the macroeconomic performance of oil exporting developing countries, and exchange rate is one of the prominent macroeconomic indicators worthy of analysis in the oil price-effects framework. It is a stylized fact that the real exchange rate can be affected by oil prices through the term of trade and the terms of trade is affected through a spending and a resource shift effects [2].

In addition, the monetary policies of African oil producing countries are strongly tied to oil sector and as a result, their domestic interest rates are highly vulnerable to crude oil price shocks. The unsteady movements in crude oil price have continued to exacerbate monetary policy dynamics in the African oil producing countries. The reason behind the incessant changes in their monetary policy outlooks is the downward volatility in crude oil price which has compounded monetary policy uncertainty [3]. The monetary policy uncertainty as a result of crude oil price volatility therefore has some implications on the overall output performance of African oil producing countries. In this regard, it therefore appears that the interaction between monetary policy and the production sector of the African oil producing countries calls for empirical investigation.

Several empirical studies have examined the relationship between crude oil price shocks and economic growth in Africa. However, there are only a handful of studies that investigate whether exchange rate regime and interest rate policy have a significant explanatory power of oil price implications on African oil producing economies. Meanwhile, economic theory reveals that in the presence of price stickiness, exchange rate regime and interest rate policy play a crucial role in the movement of international relative prices following global oil price shocks [4]. Consequently, this research work therefore contributes to the literatures by providing a more detailed assessment on whether the choice of exchange rate regimes and interest rate policy hold a significant explanatory power of oil price implications on African oil producing economies and to equally examine if the significance of such implications vary across the selected countries. The study also improves the existing literatures by using quarterly data and thus enabling the study lead to better model specifications

\section{LITERATURE}

Shudhasattwa and Pasquale [5] used a panel data analysis between the periods of 1970 and 1980 to examine the asymmetric impacts of oil prices on major oil exporting and importing countries. Adopting three measures of variables such as total trade balance, oil trade balance and non-oil trade balance, their results showed that a decrease in oil prices is beneficial for both total trade balance and oil trade balance in the oil exporting countries. Their results equally revealed that decline in oil prices have a negative impact on both total trade balance and oil trade balance as a result of increased oil imports in emerging economies.

Mutuku and Koechi [6] used Vector Autoregressive (VAR) method to examine the impact of fiscal and monetary policy shocks on some macroeconomic fundamentals in three emerging African economies: Ghana, Nigeria and South Africa. By adopting some macroeconomic variables like real GDP, Inflation and Trade, their results showed that these macroeconomic variables respond considerably to both contractionary and expansionary fiscal policy shocks and the 
impacts of fiscal policy shocks were more pronounced and significant than monetary policy shocks in these countries.

Apere and Ijomah [7] employed structural cointegrated VAR model for the period between 1970 and 2010 to examine the effects of oil price shock on monetary policy in Nigeria. The result revealed that there is a long-run relationship involving oil prices, inflation rate, treasury bill rate, exchange rate, interest rate and money supply in Nigeria. The results further showed that an unexpected oil price shock is followed by an increase in inflation rate, a decline in exchange rate and interest rate in Nigeria.

Englama, Omotunde and Ogunleye [8] examined the effect of oil price volatility, demand for foreign exchange and external reserves on exchange rate volatility in Nigeria between 1991 and 2009. By employing cointegration and vector error correction model, their results revealed that a $1.0 \%$ permanent increase in oil price and at the international market increases exchange rate volatility by $0.54 \%$ in the long-run, while in the short-run by $0.02 \%$. Also, a permanent $1.0 \%$ increase in demand for foreign exchange increases exchange rate volatility by $14.8 \%$ in the long-run.

Gachara [9] examined the channels through which oil price shocks affect economic activity in Kenya. The study employed Structural Vector Autoregressive (SVAR) and Granger causality test for the period between 1991 and 2014. The variables used in the study are real exchange rate, inflation, money supply, real GDP growth and international price of crude oil. Results of the study revealed that there exists a bi-directional causality between real exchange rate and inflation in Kenya. There also exists a uni-directional causality from inflation to real GDP and from real GDP to real exchange rate. The study further showed that crude oil price shocks have a significant effect on Kenya's macroeconomic performance.

\section{Methodology}

\section{A. Model Set-up}

In this research work, a four variable Structural Vector Autoregressive (SVAR) model is used. This model is similar to the one used by Raghvan, Silvapulle and Athanasopoulos [10], Pirovano [11] and Dungey and Pagan [12]. The Vector Autoregressive model assumes that each of the selected African oil producing economy (comprising of Angola, Sudan, Cameroon, Cote D'Ivoire, Nigeria, Algeria, Libya, Tunisia, Mauritania, Egypt, Republic of Congo, Gabon, Chad, Democratic Republic of Congo and Guinea) is represented by a structural form equation as follows:

$$
B(L) y_{t}=U_{t}
$$

where $B(L)$ is a matrix polynomial in the lag operator $\mathrm{L}$, such that $B(L)=B_{0}-B_{1} L-B_{2} L^{2}-B_{p} L^{p} . B_{0}$ is a non-singular matrix normalized to have ones on the diagonal and summarizes the contemporaneous relationship between the variables in the model contained in the vector $y_{t} \cdot y_{t}$ is an $N \times 1$ vector of endogenous variables which includes $\{W O P, I N F R, E X R, R I N T R\} . U_{t}$ is an $N \times 1$ vector of structural disturbances with 0 mean and $\operatorname{Var}\left(U_{t}\right)=\theta$ ((where $\theta$ denotes a diagonal matrix) we presume the structural disturbances to be mutually uncorrelated. Related with this structural model is the reduced form VAR which is estimated as:

$$
A(L) y_{t}=\varepsilon_{t}
$$

where $A(L)$ is a matrix polynomial in the lag operator $\mathrm{L}, \varepsilon_{t}$ is a vector of the VAR residuals with 0 mean and $\operatorname{VAR}\left(\varepsilon_{t}\right)=$ $\sum$. The relationship between the components of equations (1) and (2) are stated as follows:

$$
A(L)=B_{0}^{-1} B(L)
$$

and

$$
\varepsilon_{t}=B_{0}^{-1} U_{t}
$$

By normalizing $N \times 1$ diagonal elements of $B_{0}$ to ones (i.e unity), we need at least $n\left[\frac{n-1}{2}\right]$ restrictions on $B_{0}$ to achieve identification.

What actually inform the adoption of SVAR in this research work instead of the traditionally used Cholesky decomposition is that the identification approach of the latter follows only a recursive method. This recursive method is commonly known to be exposed to wrong causal ordering of variables if the researcher is interested in looking at more than just monetary shocks [13]. This setback can be conveniently avoided by adopting non-recursive SVAR

\section{B. Model Identification: Non-Recursive Approach}

The method adopted to impose restrictions on the contemporaneous matrix of structural parameter $B_{0}$ in this study is based on the work of Raghvan, Silvapulle and Athanasopoulos [10], Pirovano [11] and Dungey and Pagan [12]. In this model, the vector $\left[Y_{t}:\right.$ WOP $\left., I N F R, E X R, R I N T R\right]$ is assumed to be divided into two blocks. The exogenous vector $\left[X_{t}: W O P\right]$ is assumed to be a foreign block. The foreign variable is included to control for exogenous change in the global economic stance. The endogenous vector $\left[Z_{t}: I N F R, E X R, R I N T R\right]$ is assumed to be a domestic block and policy variables. The Policy variables $[I N F R, E X R, R I N T R]$ are equally assumed to be controlled by the monetary authorities.

WOP stands for World Oil Price, INFR represents Inflation Rate, $\boldsymbol{E X} \boldsymbol{R}$ is the Exchange Rate while $\boldsymbol{R I N T R}$ stands for domestic Real Interest Rate. The equation 5 below therefore shows the non-recursive identification approach as follows:

$$
\left[\begin{array}{c}
U^{W O P} \\
U^{I N F R} \\
U^{E X R} \\
U^{R I N T R}
\end{array}\right]=\left[\begin{array}{cccc}
1 & 0 & 0 & 0 \\
a_{21} & 1 & 0 & 0 \\
a_{31} & a_{32} & 1 & a_{34} \\
a_{41} & a_{42} & 0 & 1
\end{array}\right]\left[\begin{array}{c}
\varepsilon^{W O P} \\
\varepsilon^{I N F R} \\
\varepsilon^{E X R} \\
\varepsilon^{R I N T R}
\end{array}\right]
$$

Where $U^{W O P}, U^{I N F R}, U^{E X R}, U^{R I N T R}$ are the structural disturbances on the endogenous variables respectively and $\varepsilon^{W O P}, \varepsilon^{I N F R}, \varepsilon^{E X R}, \varepsilon^{R I N T R}$ are reduced-form residual that describe the unanticipated movements of each regressor respectively.

The first row in equation 5 relates to World Oil Price (WOP) which represents foreign variable. Similar to the work 
of Raghvan et al [10], we assume that domestic shocks do not affect the external sector variable, but domestic variables are assumed to be affected by external shocks. The assumption of the contemporaneous response of Inflation to only World Oil Price in the second row is consistent with the work of Dungey and Pagan [12]. According to Pirovano [11], third row shows that the exchange rate is set in a competitive market and thus responds contemporaneously to all the variables in the model. Following the work of Pirovano [11], we allow domestic Real Interest Rate in the last row to be affected by World Oil Price and Inflation Rate while the Exchange Rate does not affect it.

\section{Sources of Data}

This paper consists of quarterly data over the period of the first quarter of 1981 to the fourth quarter of 2017. The four variables of SVAR model include the following: World Oil Price (WOP), Inflation Rate (INFR), Real Interest Rate (RINTR) and Exchange Rate (EXR). Data on WOP was sourced from International Monetary Fund (World Economic Outlook) while data on RINTR, INFR and EXR were sourced from World Bank (WDI).

\section{RESUlTS AND DisCUSSION}

\section{A. Results of SVAR Impulse Response Function}

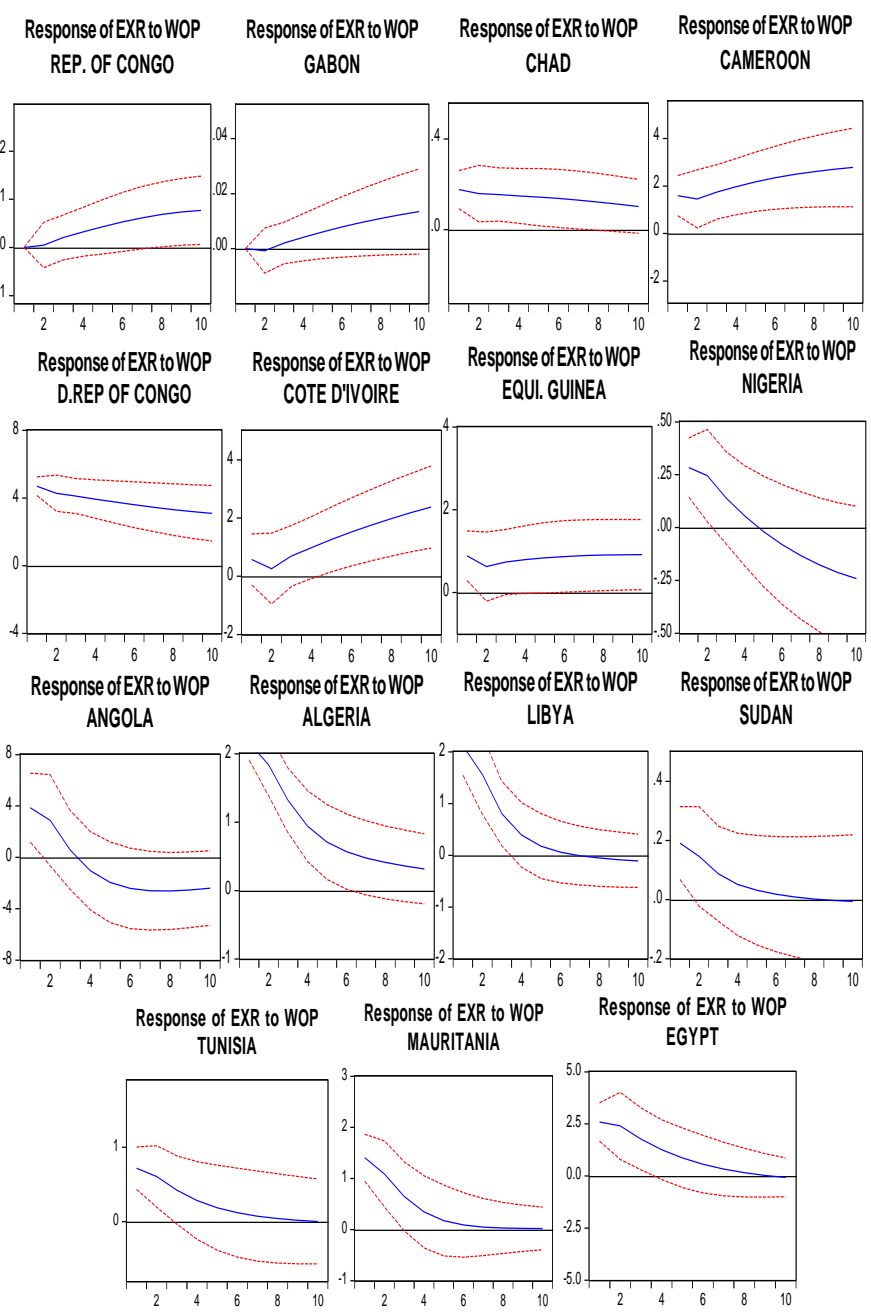

Fig. 1. Response of Exchange Rate (EXR) to World Oil Price (WOP) Shock in the Selected Oil Producing Countries in Africa.
Figure 1 above showed the response of exchange rate to world oil price in each of the selected oil producing countries in Africa. Result from the Fig. 1 confirmed that the response of exchange rate to a standard deviation shock from world oil price is positive and significant in Republic of Congo, Gabon, Chad, Cameroon, Democratic Republic of Congo, Cote d'Ivoire and Equatorial Guinea. However, the case is quite different for Nigeria and Angola as the response of exchange rate to a standard deviation shock from world oil price was positive and significant initially, but later diverged towards equilibrium at $5^{\text {th }}$ period for Nigeria and $4^{\text {th }}$ period for Angola; and start to decrease below equilibrium (negative axis) as time increases. Moreover, a critical look at the results from this Fig. 1 revealed that the shock coming from world oil price exerted similar effect on the exchange rate in Algeria, Libya, Sudan, Tunisia, Mauritania and Egypt. The response of exchange rate to a standard deviation shock from world oil price in these countries was positive and significant initially but later diverged toward equilibrium and maintained on the equilibrium line throughout the period.
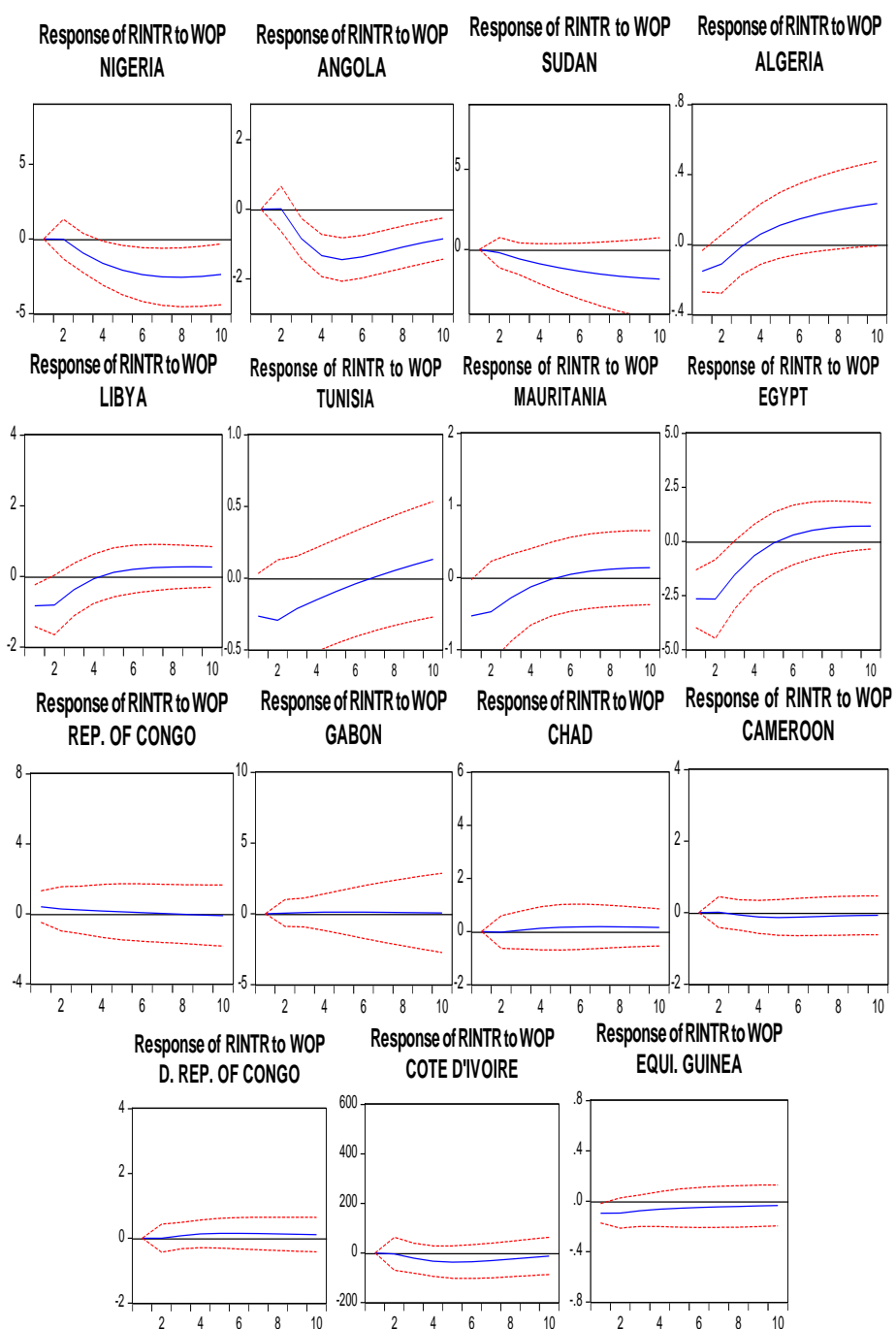

Fig. 2. Response of Real Interest Rate (RINTR) to World Oil Price (WOP) in the Selected Oil Producing Countries in Africa.

Figure 2 depicted the SVAR impulse response of domestic interest rate to a standard innovation from world oil price shock in the selected oil producing countries in Africa. Results from the figure confirmed that a standard deviation shock from world oil price has negative and significant 
impacts on domestic interest rates in Nigeria, Angola and Sudan. But the case is a little bit different for countries such as Algeria, Libya, Tunisia, Mauritania and Egypt; because the response of interest rate to a standard deviation shock from world oil price in these countries was at first negative and significant, but later deviated towards zero line and eventually rose above equilibrium (Positive axis) as time increases. However, the situation is completely different in the remaining countries like Republic of Congo, Chad, Cameroon, Democratic Republic of Congo, Cote D'Ivoire and Equatorial Guinea as the response of interest rate to a shock from world oil price is insignificant during the period under review.

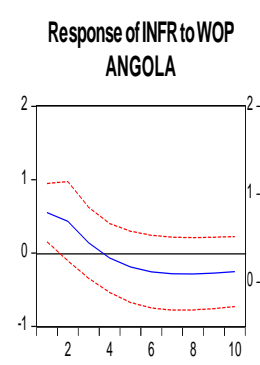

Response of INFR to WOP ALGERIA

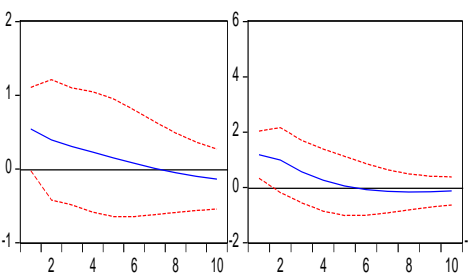

NIGERIA

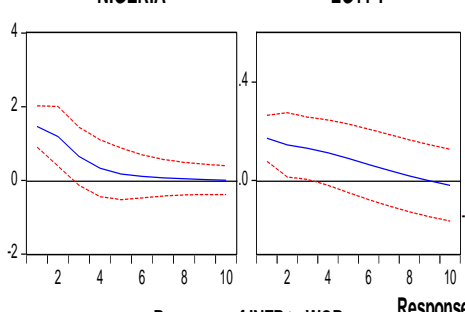

EGYPT
Response of NFRT to WOP Responseof INFRT WOP CAMEROON

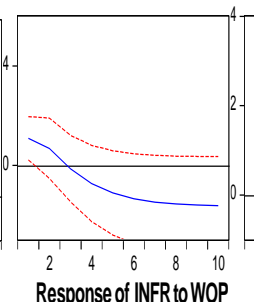
TUNISIA

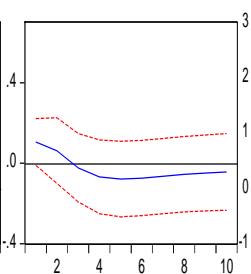

Response REP. OF CONGO

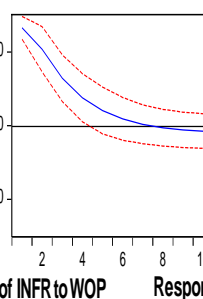

Response of IN

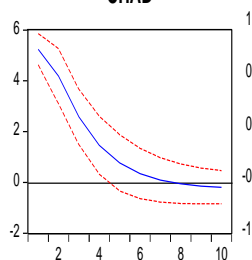
D. REP. OF CONGO

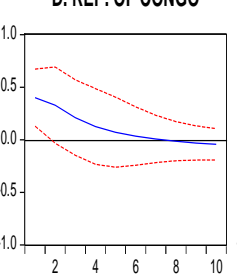

Fig. 3. Response of Inflation Rate (INFR) to World Oil Price (WOP) Shock in the Selected Oil Producing Countries in Africa

Figure 3 above presented the response of inflation rate to world oil price shock in the selected oil producing countries in Africa. Results from the figure depicted that the response of inflation rate to a standard deviation shock from world oil price was positive and significant initially but diverged towards equilibrium and later decreased below equilibrium (i.e. negative axis) as time increases. In addition, the impact of a standard deviation shock from world oil price on inflation rate produced the same initial positive results in other countries such as Nigeria, Egypt, Republic of Congo, Gabon, Chad, Democratic Republic of Congo and Equatorial Guinea.
The result was later different for these countries as the response of inflation to the shock from world oil price eventually diverged towards equilibrium and maintained on the equilibrium line throughout the period.

\section{B. Discussion of Findings}

The SVAR Impulse Response Function results in this research work showed that the response of exchange rate to a standard deviation shock coming from World Oil Price (WOP) is positive and significant in some African oil producing countries such as Republic of Congo, Gabon, Chad, Cameroon, Democratic Republic of Congo, Cote D'Ivoire and Equatorial Guinea. A careful assessment of these countries revealed that they belong to a union called Central African Economic and Monetary Community (CEMAC) except Cote D'Ivoire that belongs to the sister union known as West Africa Economic Monetary Union (WAEMOA). One major attribute of countries that belong to these two unions is that they share the same currency (i.e. the CFA Franc) which is pegged to the Euro. This therefore implies that these countries adopt fixed exchange rate policy.

In this regard, the positive and significant response of exchange rate to World Oil Price shock might be attributed to the certainty and stability feature attached to the fixed exchange rate policy adopted in these countries. According to Gylfason [14], stable exchange rate policy tends to stimulate foreign trade and economic efficiency as a result of predictable climate for investment, therefore bringing forth more proceeds from exports and appreciating exchange rate. So, with an increase in the global oil price coupled with a predictable economic environment brought about by fixed exchange rate policy, these countries will still experience appreciation in the foreign exchange rate. In addition, findings from the same SVAR impulse response function results confirmed that the response of exchange rate to world oil price shocks was initially positive but later declined to the negative axis, as time goes on in Nigeria and Angola. The implication of the findings from this result is that both Nigeria and Angola benefitted immensely from the merit of fixed exchange rate when they adopted the policy but later lost it when they shifted to floating exchange rate. The uncertainty and risk associated with floating exchange rate might discourage potential investors, thereby reducing earnings from export and thus depreciate domestic currency in the face of other countries' currencies. Even, if there is an increase in the global oil price, there will still be depreciation in exchange rate as a result of risky economic environment brought about by the high exchange rate volatility.

Also, still from the same SVAR impulse response function results, findings from this result showed that the response of exchange rate to world oil price shocks was initially positive and significant but later became insignificant as it remained on the equilibrium line as time increases in Angola, Algeria, Libya, Sudan, Tunisia, Mauritania, and Egypt. Critical examination of these countries proved that they all belong to the Council of Arab Economic Unity (CAEU). The major attribute of these countries as regards to the adoption of exchange rate policy is that most of them had once in the past adopted fixed exchange rate policy but they are currently adopting intermediate exchange rate regime which shares certain degrees of both fixed and floating exchange rate 
policies [15]. The adoption of this intermediate exchange rate policy might be responsible for the insignificant response of exchange rate to the shock coming from world oil price in these countries.

Moreover, findings from the SVAR impulse response function confirmed that a standard deviation shock from world oil price has negative and significant impacts on domestic interest rates in Nigeria, Angola and Sudan. But the case is quite different for countries such as Algeria, Libya, Tunisia, Mauritania and Egypt; because the response of interest rate to a standard deviation shock from world oil price in these countries was at first negative and significant, but later deviated to Positive axis as time increases. However, the situation is completely different in the remaining countries like Republic of Congo, Chad, Cameroon, Democratic Republic of Congo, Cote D'Ivoire and Equatorial Guinea as the response of interest rate to a shock from world oil price is insignificant.

The cause of variances in the findings from these results might be as a result of different monetary policy regimes employed by some of these countries. A critical examination of some countries such as Nigeria, Angola and Sudan showed that these countries adopted expansionary monetary policy through the reduction in interest rates. A decrease in interest rate therefore enhances investment and total productivity even during a decline in the global oil price. High proceed from total productivity is sufficient enough to payoff for any negative impacts of a fall in global oil price. This is the reason why the response of domestic interest rate to world oil price shock is negative and significant in these three countries (i.e. Nigeria, Angola and Sudan). This finding aligns with the work of Taiwo [16].

Also, a careful assessment of some countries like Algeria, Libya, Tunisia, Mauritania, and Egypt revealed that these countries employed contractionary monetary policy through the increase in interest rate in the later period of these countries. The increase in interest rate impairs investment growth thereby leading to a decline in output growth. Decline in the output growth will be insufficient to compensate for some of the negative outcomes that arise during a decline in the global oil price in these countries. Moreover, the insignificant response of domestic interest rate to world oil price shock in the remaining countries like Republic of Congo, Gabon, Chad, Cameroon, Democratic Republic of Congo, Cote d'Ivoire and Equatorial Guinea might be hinged on the pegged exchange rate policy employed by these countries. This fixed exchange rate regime often constraints the monetary authorities to establish independent monetary policy through the variability of interest to regulate some of the negative shock of oil price fall [18].

\section{CONClusion And POLICY RECOMMENDATION}

According to the results and discussion of findings in this study, it is concluded that there may not be a right choice for all oil producing countries in Africa as regard to which is best among fixed, floating and intermediate exchange rate as all the three exchange rate regimes have their costs and benefits considering the economic situations available at a point in time. This study also concludes that expansionary monetary policy (in which interest rate is reduced to stimulate investment) is more effective in insulating against and compensating for the negative effect of the decline in global oil price in the selected oil producing countries in Africa.

In view of all the aforementioned findings in this research work, the following recommendations are made:

As it was observed in this study that no exchange rate regime is best and no one is bad for African oil producing countries, judging from the costs and benefits that are associated with the three major exchange rate regimes (i.e. fixed exchange rate, floating exchange rate and intermediate exchange rate). In this regard, rather than focusing on the choice of exchange rate regime, the best way for the country that is operating any of the three exchange rate systems at any point in time is to design strategies to improve upon the benefits and to reduce costs that are associated with any of the three exchange rate systems.

For instance, floating exchange rate is known for bringing about automatic adjustment of monetary policy to regulate and confront any external shocks that might affect any African oil producing countries negatively. However, the same floating exchange rate is equally known for unpredictable and risky economic environment, thereby retarding investment and growth. This side effect of the floating exchange rate can be avoided and bring about a positive relationship between the level of uncertainty and investment only if the levels of risk aversion are sufficiently low. This can effectively be done by reducing the riskpremium embedded in its interest rate, as a lower interest rate will definitely encourage investment even in the face of any risk and uncertainty.

Furthermore, fixed exchange rate is known to be beneficial by bringing about a predictable economic environment thereby stimulating investment and growth. But this same fixed exchange rate is faulty as it is incapable of absorbing external shocks due to the difficulties of monetary authorities to conduct independent monetary policy through adjustment in the interest rate to regulate the exchange rate volatility. This cost associated with fixed exchange rate can be avoided by improving strongly the fiscal, financial and monetary institutions, because firms that are active in any economy with well-developed fiscal, financial and monetary institutions will cope better with the aggregate shocks, thereby promoting a tendency for firms to pursue long-term investment.

Lastly, an effective and efficient expansionary monetary policy should be put in place in the oil producing countries in Africa. This is done by cutting down the cost of capital (i.e. interest rate) as this will stimulate investment and growth.

\section{REFERENCE}

[1] Hasanov, F. (2010). The Impact of Real Oil Price on Real Effective Exchange Rate: The Case of Azerbaijan. Discussion Paper Series 1041. Berlin: DIW Berlin German Institute for Economic Research.

[2] Korhonen, I. \& Juurikkala, T. (2009). Equilibrium exchange rates in oil exporting countries. Journal of Economics and Finance, 33(1), 7179.

[3] IMF (2017). International Monetary Fund economic report: Africa focus special, (47), 13-28.

[4] Levy-Yeyati, E. \& Sturzenegger, F. (2005). To float or to fix: evidence on the impact of exchange rate regimes on growth. American Economic Review, 1173-1193. 
[5] Shudhasattwa, G. \& Pasquale, M. (2015). Asymmetric Impacts of oil Prices on Oil Exporting and Importing countries. International Economic Review 50(4), 243-266.

[6] Mutuku, B. \& Koech, C. (2014). 'Monetary Policy, Fiscal Policy and Economic Growth in emerging African economies: Ghana, Nigeria and South Africa. American Economc Review, 91, 964-985.

[7] Apere, O. \& Ijomah, A. M. (2013). Macroeconomic impact of oil price levels and volatility in Nigeria. International Journal of Academic Research in Economics and Management Sciences, 2(4), 15-25.

[8] Englama, A., Omotunde, O. \& Ogunleye, T. S (2010). Oil Prices and Exchange rate volatility in Nigeria: An empirical investigation. Central Bank of Nigeria (CBN) Economic and financial review 48/3.

[9] Gachara, K. (2015). 'Oil price Shocks and Economic Activity in Kenya' A Structural VAR Approach, The Journal of Economic Perspectives, 18(4), 115-134.

[10] Raghvan, M., Silvapulle, P. \& Athanasopoulos, G. (2012). Structural VAR model for Malaysian Monetary Policy analysis during the Pre and Post 1997 Asian Crisis Periods. Applied Economics, 44(29), 38413856.

[11] Pirovano, M. (2012). Monetary Policy and Stock prices in Small Open Economies. Empirical Evidence for the New EU Members States. Economic Systems. 36(5), 372-390.

[12] Dungey, M. \& Pagan, A. (2000). A structural VAR model of the Australian economy. Economic Record, 76, 321-342.

[13] Gottschalk, J. (2001). An Introduction into the SVAR Methodology. Identification, Interpretation and Limitations of SVAR models. Kie working paper, No. 1072.

[14] Gylfason, T. (2000). Fix or flex? Alternative exchange rate regimes in an Era of global capitalmobility. North American Journal of Economics and Finance, 11(2),173-189.

[15] Petreski, M. (2009). Exchange-rate regime and economic growth: $A$ review of the theoretical and empirical literature, Economics. Kiel Institute for the World Economy, Kiel, 2009-31.

[16] Taiwo, M. (2011). Investment, inflation and economic growth: empirical evidence from Nigeria. Research Journal of Finance and Accounting, 2(5), 68-76.

[17] Gancia, H. \& Malet, F. (2007). Are the Monetary Output Effects Asymmetric? Economic Inquiry, 40(3), 102-119.

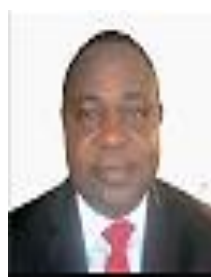

Adedeji, Adetona Sikiru (FCA, ACIB, Ph.D) currently serves as a Deputy Director in the Department of Banking Supervision, Central Bank of Nigeria. He is a Fellow Chartered Accountants of Nigeria and an Associate Chartered Institute of Bankers of Nigeria. His areas of research interest are Monetary and Development Economics.

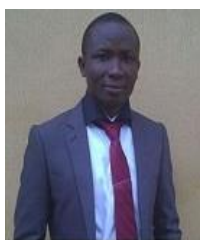

Saliu, Mojeed Olanrewaju (Ph.D) currently lectures in the Department of Economics, Ekiti State University, Ado-Ekiti, Nigeria. He is a Member of Nigerian Economic Society. His areas of research interest are Monetary and Industrial Economics. 